\title{
In Vitro Changes in Secretion Activity of Rat Ovarian Fragments Induced by Molybdenum
}

\author{
S. ROYCHOUDHURY ${ }^{1}$, L. DETVANOVA ${ }^{2}$, A. V. SIROTKIN ${ }^{3}$, R. TOMAN ${ }^{4}$, \\ A. KOLESAROVA ${ }^{2}$
}

${ }^{1}$ Department of Life Science and Bioinformatics, Assam University, Silchar, India, ${ }^{2}$ Department of Animal Physiology, Faculty of Biotechnology and Food Sciences, Slovak University of Agriculture, Nitra, Slovak Republic, ${ }^{3}$ Animal Production Research Centre Nitra, National Agricultural and Food Centre, Luzianky, Slovak Republic, ${ }^{4}$ Department of Veterinary Sciences, Faculty of Agrobiology and Food Resources, Slovak University of Agriculture, Nitra, Slovak Republic

Received May 29, 2014

Accepted August 8, 2014

On-line August 26, 2014

\section{Summary}

The aim of this in vitro study was to examine the secretion activity (progesterone, 17 $\beta$-estradiol and insulin-like growth factor-I) of rat ovarian fragments after molybdenum (Mo) addition. Rat ovarian fragments were incubated with ammonium molybdate $\left(\mathrm{NH}_{4}\right)_{6} \mathrm{Mo}_{7} \mathrm{O}_{24} .4 \mathrm{H}_{2} \mathrm{O}$ at the doses $90,170,330$ and $500 \mu \mathrm{g} \cdot \mathrm{ml}^{-1}$ for $24 \mathrm{~h}$ and compared with control group without Mo addition. Release of progesterone $\left(\mathrm{P}_{4}\right)$, estradiol (17ß-estradiol) and insulin-like growth factor I (IGF-I) by ovarian fragments was assessed by radioimmunoassay (RIA). Data show that $\mathrm{P}_{4}$ release by ovarian fragments was not affected by $\left(\mathrm{NH}_{4}\right)_{6} \cdot \mathrm{Mo}_{7} \mathrm{O}_{24} \cdot 4 \mathrm{H}_{2} \mathrm{O}$ addition at all the doses used (90-500 $\left.\mu \mathrm{g} \cdot \mathrm{ml}^{-1}\right)$. However, addition of ammonium molybdate was found to cause a significant $(P<0.05)$ dose-dependent decrease (at the doses 90,170 and $500 \mu \mathrm{g} \cdot \mathrm{ml}^{-1}$ ) in release of $17 \beta$-estradiol by ovarian fragments in comparison to control. Also, addition of ammonium molybdate significantly $(P<0.05)$ inhibited IGF-I release at all the doses $\left(90-500 \mu \mathrm{g} \cdot \mathrm{ml}^{-1}\right)$ used in the study. Results suggest ammonium molybdate induced inhibition in the release of growth factor IGF-I and its dosedependent effect on secretion of steroid hormone $17 \beta$-estradiol but not progesterone. These data contribute to new insights regarding the mechanism of action of Mo on rat ovarian functions.

\section{Key words}

Molybdenum • Rat Ovary • Progesterone • Estradiol • IGF-I

\section{Corresponding author}

A. Kolesarova, Department of Animal Physiology, Faculty of Biotechnology and Food Sciences, Slovak University of Agriculture, 94976 Nitra, Slovak Republic. E-mail: Adriana.Kolesarova@uniag.sk

Molybdenum is an important cofactor for enzymes including xanthine oxidoreductase, aldehyde oxidase and sulfide oxidase in animals (Mendel 2007). Polyoxomolybdates as discrete molybdenum-oxide cluster anions provide promising, novel anti-tumor agents, especially for cancers that are difficult to treat (Ogata et al. 2008). Female reproductive functions can be compromised by exposure to potentially toxic chemicals at a variety of sites, including ovary or reproductive tract (Mlynarcikova et al. 2005). Ovarian follicular growth and differentiation are governed by hormones and growth factors (Roychoudhury et al. 2014). The aim of this study was to examine the secretion activity $\left(\mathrm{P}_{4}, 17 \beta\right.$-estradiol and IGF-I) of rat ovarian fragments after addition of ammonium molybdate in vitro. Ovarian fragments (total 125 pieces) of $2 \mathrm{~mm}$ size obtained from 130 day old healthy Wistar rats $(n=25)$ according to EU and Slovak 
guidelines for animal care, manipulation and use, were washed in sterile DMEM/F121:1 media (BioWhittaker, Verviers, Belgium) and incubated for $24 \mathrm{~h}$ in culture plates (Nunc, Roskilde, Denmark, $1 \mathrm{ml}$ medium/well) in the same media with $10 \%$ FCS and $1 \%$ antibioticantimycotic solution (Sigma, St. Louis, MO, USA) without (Control group) or with ammonium molybdate $\left(\mathrm{NH}_{4}\right)_{6} \cdot \mathrm{Mo}_{7} \mathrm{O}_{24} \cdot 4 \mathrm{H}_{2} \mathrm{O} \quad\left(81.0-83.0 \% \quad \mathrm{MoO}_{3}\right.$ basis; molecular weight 1235.86; Sigma-Aldrich, St. Louis, USA) at the doses $90 \mu \mathrm{g} \cdot \mathrm{ml}^{-1}$ (Group A), $170 \mu \mathrm{g} \cdot \mathrm{ml}^{-1}$ (Group B), $330 \mu \mathrm{g} \cdot \mathrm{ml}^{-1}$ (Group C) and $500 \mu \mathrm{g} \cdot \mathrm{ml}^{-1}$ (Group D), respectively. Concentrations of $\mathrm{P}_{4}$, $17 \beta$-estradiol and IGF-I were determined in $25-100 \mu \mathrm{l}$ incubation medium by RIA. The rates of substance secretion were calculated per $\mathrm{mg}$ tissue per day. Significant differences (means \pm SD) between control and experimental groups $(P<0.05)$ were evaluated by using two-way ANOVA and paired $t$-test using statistical software Sigma Plot 11.0. Release of $\mathrm{P}_{4}$ by ovarian fragments did not change significantly in any of the experimental groups after addition of ammonium molybdate at the doses $90,170,330$ and $500 \mu \mathrm{g} \cdot \mathrm{ml}^{-1}$ in comparison to control. Thus, addition of ammonium molybdate had no effect on $\mathrm{P}_{4}$ release at the doses used in the study $\left(90-500 \mu \mathrm{g} \cdot \mathrm{ml}^{-1}\right)$. Release of $17 \beta$-estradiol by ovarian fragments was significantly inhibited in the experimental groups $\mathrm{A}, \mathrm{B}$ and $\mathrm{D}$ after ammonium molybdate addition at the doses 90, 170 and $500 \mu \mathrm{g} \cdot \mathrm{ml}^{-1}$ in comparison to control. However, release of $17 \beta$-estradiol was similar to that of control group at the dose $330 \mu \mathrm{g} \cdot \mathrm{ml}^{-1}$ after ammonium molybdate addition. Hence, Mo addition caused dose-dependent inhibition in the release of $17 \beta$-estradiol (Fig. 1). IGF-I release by ovarian fragments was significantly $(P<0.05)$ inhibited at all the experimental doses $\left(90-500 \mu \mathrm{g} \cdot \mathrm{ml}^{-1}\right)$ used in the study in comparison to control (Fig. 2). In another study, rabbits fed commercial pellets and carrots containing $39 \mathrm{mg} \cdot \mathrm{kg}^{-1}$ DM Mo and with a commercial diet supplemented with $40 \mathrm{mg} \cdot \mathrm{kg}^{-1} \mathrm{DM}$ Mo for 14 days did not have adverse affect on growth (Bersenyi et al. 2008). Molybdenum administered as thiomolybdate can adversely affect the hypothalamo-adenohypophyseal axis by interfering with trophic hormone release, leading to the cessation of reproductive activity and ultimately the failure of intermediary metabolism. Whether Mo exerts its effect centrally or directly on the pituitary has not been established (Haywood et al. 2004). The target specificity of tetrathiomolybdate, an anti-angiogenic, anti-tumor agent against the viability/proliferation of arterial, venous, capillary endothelial and tumor cells was examined (Carpenter et al. 2007). Venous and capillary endothelial proliferation were found to be important targets in tetrathiomolybdate therapy, but other vascular segments and tumor cells may be less influenced. Potential anticancer, cytostatic and cytotoxic effects of piroxicam complexes with $\mathrm{MoO}_{2}^{2+}$ on human promyelocytic leukemia HL-60 cells have also been investigated (Christofis et al. 2005).

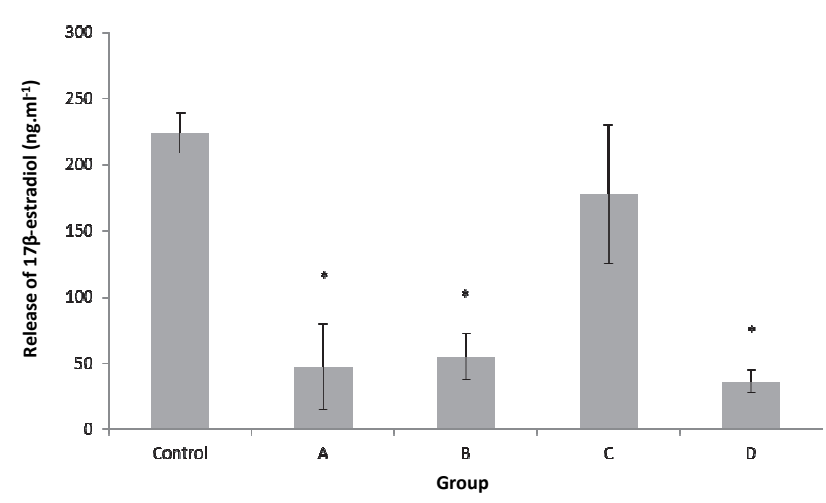

Fig. 1. Effect of molybdenum on release of $17 \beta$-estradiol by rat ovarian fragments. $*$ Control represents culture media without Mo addition. Groups $A, B$ and $D$ received $\left(\mathrm{NH}_{4}\right)_{6} \cdot \mathrm{Mo}_{7} \mathrm{O}_{24} \cdot 4 \mathrm{H}_{2} \mathrm{O}$ at $90 \mu \mathrm{g} \cdot \mathrm{m}^{-1}, 170 \mu \mathrm{g} \cdot \mathrm{ml}^{-1}$ and $500 \mu \mathrm{g} \cdot \mathrm{ml}^{-1}$ respectively, which showed decreased release of estradiol; group C $330 \mu \mathrm{g} \cdot \mathrm{ml}^{-1}$ $\left(\mathrm{NH}_{4}\right)_{6} \cdot \mathrm{Mo}_{7} \mathrm{O}_{24} \cdot 4 \mathrm{H}_{2} \mathrm{O} ;$ values are means $\pm \mathrm{SD}$. *Significant differences $(P<0.05)$ from control were evaluated by paired $t$-test.

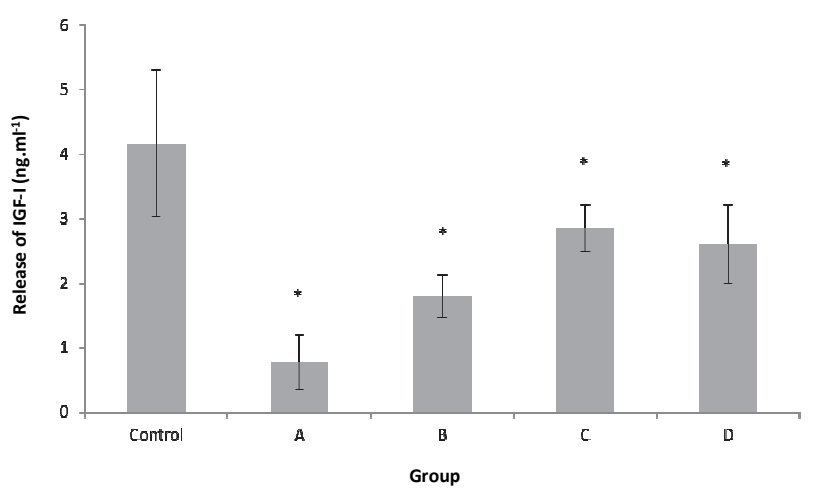

Fig. 2. Effect of molybdenum on release of IGF-I by rat ovarian fragments. *Control represents culture media without Mo addition. Groups $\mathrm{A}, \mathrm{B}, \mathrm{C}$ and $\mathrm{D}$ received $\left(\mathrm{NH}_{4}\right)_{6} \cdot \mathrm{Mo}_{7} \mathrm{O}_{24} \cdot 4 \mathrm{H}_{2} \mathrm{O}$ at doses $90 \mu \mathrm{g} \cdot \mathrm{ml}^{-1}, 170 \mu \mathrm{g} \cdot \mathrm{ml}^{-1}, 330 \mu \mathrm{g} \cdot \mathrm{ml}^{-1}$, and $500 \mu \mathrm{g} \cdot \mathrm{ml}^{-1}$ respectively, which showed decreased release of IGF-I. Values are means \pm SD. *Significant differences $(P<0.05)$ from control were evaluated by paired $t$-test.

The role of Mo in the control of rat ovarian fragments related to $\mathrm{P}_{4}, 17 \beta$-estradiol and IGF-I was investigated. In the present study, isolated rat ovarian fragments released steroid hormone progesterone, 
$17 \beta$-estradiol and IGF-I after experimental addition of ammonium molybdate in vitro. In fact, ammonium molybdate addition did not have any influence on $\mathrm{P}_{4}$ release by rat ovarian fragments at the doses used in the study. However, in chicken ovarian granulosa cells the doses $170 \mu \mathrm{g} \cdot \mathrm{ml}^{-1}$ and $330 \mu \mathrm{g} \cdot \mathrm{ml}^{-1}$ ammonium molybdate (corresponding to groups $\mathrm{B}$ and $\mathrm{C}$ respectively in the present study) were reportedly associated with stimulation of $\mathrm{P}_{4}$ release (Kolesarova et al. 2009). Furthermore, ammonium molybdate addition caused dose-dependent inhibition in the release of $17 \beta$-estradiol by rat ovarian fragments particularly at the doses $90 \mu \mathrm{g} \cdot \mathrm{ml}^{-1}, \quad 170 \mu \mathrm{g} \cdot \mathrm{ml}^{-1}$ and $500 \mu \mathrm{g} \cdot \mathrm{ml}^{-1}$. Also, ammonium molybdate addition inhibited IGF-I release at all the doses used in the study (90-500 $\left.\mu \mathrm{g} \cdot \mathrm{ml}^{-1}\right)$. These findings confirm previous reports about dose-dependent influence of Mo on decreasing the IGF-I release by chicken ovarian granulosa cells at the dose $330 \mu \mathrm{g} . \mathrm{ml}^{-1}$ ammonium molybdate corresponding to group $\mathrm{C}$ in the present study (Kolesarova et al. 2009), and by porcine ovarian granulosa cells at the dose $500 \mu \mathrm{g} . \mathrm{ml}^{-1}$ ammonium molybdate which is the highest dose used in the present study corresponding to group D (Kolesarova et al. 2011). These results suggest Mo induced inhibition in the release of growth factor IGF-I and its dosedependent effect on secretion of steroid hormone $17 \beta$-estradiol but not progesterone. The data contribute to new insights regarding the mechanism of action of Mo on rat ovarian functions.

\section{Conflict of Interest}

There is no conflict of interest.

\section{Acknowledgements}

This work was supported by the Ministry of Education, Science, Research and Sports of the Slovak Republic (1/0022/13, 1/0532/11), Slovak Research and Development Agency of the Slovak Republic (APVV0304-12) and the Department of Biotechnology, Government of India (BT/265/NE/TBP/2011).

\section{References}

BERSENYI A, BERTA E, KADAR I, GLAVITS R, SZILAGYI M, FEKETE SG: Effects of high dietary molybdenum in rabbits. Acta Vet Hung 56: 41-55, 2008.

CARPENTER A, RASSAM A, JENNINGS MH, ROBINSON-JACKSON S, ALEXANDER JS, ERKURAN-YILMAZ $\mathrm{C}$ : Effects of ammonium tetrathiomolybdate, an oncolytic/angiolytic drug on the viability and proliferation of endothelial and tumor cells. Inflamm Res 56: 515-519, 2007.

CHRISTOFIS P, KATSAROU M, PAPAKYRIAKOU A, SANAKIS Y, KATSAROS N, PSOMAS G: Mononuclear metal complexes with Piroxicam: Synthesis, structure and biological activity. J Inorg Biochem 99: 2197-2210, 2005.

HAYWOOD S, DINCER Z, JASANI B, LOUGHRAM MJ: Molybdenum-associated pituitary endocrinopathy in sheep treated with ammonium tetrathiomolybdate. J Comp Pathol 130: 21-31, 2004.

KOLESAROVA A, CAPCAROVA M, SIROTKIN AV, MASSANYI P: Insulin like growth factor-I and progesterone release by ovarian granulosa cells of hens after experimental lead and molybdenum administrations in vitro. Int J Poultry Sci 8: 890-895, 2009.

KOLESAROVA A, CAPCAROVA M, SIROTKIN AV, MEDVEDOVA M, KALAFOVA A, FILIPEJOVA T, KOVACIK J: In vitro assessment of molybdenum-induced secretory activity, proliferation and apoptosis of porcine ovarian granulosa cells. J Environ Sci Health A Tox Hazard Subst Environ Eng 46: 170-175, 2011.

MENDEL RR: Biology of the molybdenum cofactor. J Exper Bot 58: 2289-2296, 2007.

OGATA A, YANAGIE H, ISHIKAWA E, MORISHITA Y, MITSUI S, YAMASHITA A, HASUMI K, TAKAMOTO S, MLYNARCIKOVA A, FICKOVA M, SCSUKOVA S: Ovarian intrafollicular processes as a target for cigarette smoke components and selected environmental reproductive disruptors. Endocr Regul 39: 21-32, 2005.

ROYCHOUDHURY S, BULLA J, SIROTKIN AV, KOLESAROVA A: In vitro changes in porcine ovarian granulosa cells induced by copper. J Environ Sci Health A Tox Hazard Subst Environ Eng 49: 625-633, 2014.

YAMASE T, ERIGUCHI M: Antitumour effect of polyoxomolybdates: Induction of apoptotic cell death and autophagy in in vitro and in vivo models. Br J Cancer 98: 399-409, 2008. 